\title{
Effects of Single and Double Infections of Winter Wheat by Triticum mosaic virus and Wheat streak mosaic virus on Yield Determinants
}

E. Byamukama, Department of Plant Pathology, S. Tatineni, United States Department of Agriculture-Agricultural Research Service
(USDA-ARS) and Department of Plant Pathology, G. L. Hein, Department of Entomology, R. A. Graybosch, USDA-ARS and Depart-
ment of Agronomy and Horticulture, P. S. Baenziger, Department of Agronomy and Horticulture, R. French, USDA-ARS and Department of Plant Pathology, and S. N. Wegulo, Department of Plant Pathology, University of Nebraska-Lincoln, Lincoln 68583

\begin{abstract}
Byamukama, E., Tatineni, S., Hein, G. L., Graybosch, R. A., Baenziger, P. S., French, R., and Wegulo, S. N. 2012. Effects of single and double infections of winter wheat by Triticum mosaic virus and Wheat streak mosaic virus on yield determinants. Plant Dis. 96:859-864.

Triticum mosaic virus (TriMV) is a recently discovered virus infecting wheat (Triticum aestivum) in the Great Plains region of the United States. It is transmitted by wheat curl mites (Aceria tosichella) which also transmit Wheat streak mosaic virus (WSMV) and Wheat mosaic virus. In a greenhouse study, winter wheat 'Millennium' (WSMV susceptible) and 'Mace' (WSMV resistant) were mechanically inoculated with TriMV, WSMV, TriMV+WSMV, or sterile water at the two-leaf growth stage. At 28 days after inoculation, final chlorophyll meter (soil plant analysis development [SPAD]) readings, area under the SPAD progress curve (AUSPC), the number of tillers per plant, shoot and root weight, and total nitrogen and carbon content were determined. In Millennium, all measured variables were significantly reduced by sin-

gle or double virus infections, with the greatest reductions occurring in the double-infection treatment. In Mace, only final SPAD readings, AUSPC, and total nitrogen were significantly reduced by single or double virus infections. There was a significant $(P \leq 0.05)$, positive linear relationship between SPAD readings and shoot weight in Millennium but not in Mace. The relationship between total nitrogen and shoot weight was positive, linear, and significant in both cultivars. The results from this study indicate that Mace, a WSMV-resistant cultivar, is also resistant to TriMV, and double infection of winter wheat by TriMV and WSMV exacerbates symptom expression and loss of biomass in susceptible cultivars.
\end{abstract}

Triticum mosaic virus (TriMV) (genus Poacevirus, family Potyviridae) is a newly discovered virus that infects winter wheat (Triticum aestivum L.) in the Great Plains region of the United States $(5,29)$. Since the first report in Kansas in 2006, TriMV has been found in Nebraska, South Dakota, Montana, Colorado, Texas, Wyoming, and Oklahoma (5; M. Burrows, unpublished data). TriMV has been found infecting wheat alone or in combination with Wheat streak mosaic virus (WSMV) (Tritimovirus, Potyviridae) and Wheat mosaic virus (WMoV)/High Plains Virus (HPV) (unassigned, Bunyaviridae) (5,27). All three viruses are transmitted by wheat curl mites (WCM; Aceria tosichella Keifer) and are among many viruses reported to infect wheat in the central Great Plains $(28,29)$. Seifers et al. (26) and Tatineni et al. (33) showed that the host range of TriMV included barley (Hordeum vulgare L.), oat (Avena sativa L.), rye (Secale cereale L.), triticale (X. Triticosecale Wittmact), and several grass species.

TriMV is a single-stranded positive-sense RNA virus with one open reading frame that encodes a polyprotein of $352 \mathrm{kDa}$ (34). The complete genome sequence distinctively showed TriMV to belong to the family Potyviridae and to have 47 to $65 \%$ amino acid sequence similarity with Sugarcane streak mosaic virus (Poacevirus, Potyviridae) (34). TriMV infection elicits cultivarspecific symptoms that include systemic chlorotic streaks, mosaic, and mottling (33). Chlorotic streak and mottling symptoms indicate depletion of chlorophyll. TriMV co-infects wheat with WSMV synergistically, leading to enhanced symptom expression

Corresponding author: S. N. Wegulo, E-mail: swegulo2@unl.edu

The findings and conclusions in this article do not necessarily reflect the view of United States Department of Agriculture.

Accepted for publication 13 January 2012.

http://dx.doi.org/10.1094/PDIS-11-11-0957-RE

(C) 2012 The American Phytopathological Society and increased titer of both viruses in susceptible wheat cultivars (33).

WSMV is by far the most prevalent and the most economically important virus infecting winter wheat in the Great Plains region of the United States $(5,31,32,37,39)$. Management of WSMV is mainly through removal of volunteer wheat and other alternative weed hosts which act as a "green bridge" for viruliferous WCM between the summer-harvested and fall-sown winter wheat crops (5). Another WSMV management strategy is the use of host resistance. Only a few winter wheat cultivars with highly effective resistance to WSMV are available $(8,11,22)$ and some wheat lines with resistance to the disease have recently been identified $(20,30)$. Cultivars with moderate resistance to WSMV have not been reported. With the discovery of TriMV and the fact that both WSMV and TriMV are transmitted by the same vector, there is a need to reevaluate resistance to WSMV when wheat is co-infected with both viruses. Lommel et al. (19) showed that, in winter wheat, resistance to Wheat soilborne mosaic virus (Furovirus, Virgaviridae) broke down in the presence of Wheat spindle streak mosaic virus (Bymovirus, Potyviridae) infection, indicating that the presence of a second virus in a host can cause resistance to the first virus to be ineffective.

The number of fertile tillers (tillers with spikes) is an important yield determinant in winter wheat (4). Few studies have reported the effect of virus infection on tillers in winter wheat and other virus host crops (14-17). Larsen et al. (17) found no significant effect of WSMV infection on the number of tillers at 21 days after inoculation (DAI). Hunger et al. (14) reported up to $75 \%$ reduction in fertile tillers for seven winter wheat cultivars inoculated with WSMV in the fall. Shahwan and Hill (31) reported up to $93 \%$ reduction in fertile tillers when eight winter and four spring wheat cultivars were inoculated with WSMV in the greenhouse. Information is lacking on the effect of TriMV infection of wheat alone or in combination with WSMV on yield determinants such as number of tillers and plant biomass. Such information can be used to predict the expected yield loss when wheat is co-infected by both viruses. This information can, in turn, enable producers 
to make informed decisions regarding profitability and choice of cultivars.

Infection of winter wheat by WSMV has been shown to reduce shoot and root growth as well as yield. Larsen et al. (17) reported that 'Homestead' and 'Scout 66' wheat, both susceptible to WSMV, had similar reductions in their shoot or root growth when inoculated with the virus in the greenhouse. Price et al. (24) showed that, when a susceptible and a resistant cultivar were inoculated with WSMV in the greenhouse, reduction in root weight and shoot biomass was greater in the susceptible than in the resistant cultivar. The same study (24) demonstrated that, under field conditions, when the same cultivars were inoculated with WSMV, reductions in aboveground biomass and grain yield were greater in the susceptible compared with the resistant cultivar. Shahwan and Hill (31) reported significant reductions in the yield of eight winter and four spring wheat cultivars when inoculated with a single isolate of WSMV under greenhouse conditions. Edwards and McMullen (6) found up to $99 \%$ grain yield reduction when 19 spring wheat cultivars were mechanically inoculated with WSMV under field conditions.

These reductions in shoot and root biomass caused by WSMV demonstrate the potentially devastating effect of the virus in winter wheat. Howell (12) demonstrated a significant positive linear relationship between aerial dry matter and grain yield in winter wheat, indicating that reduction in shoot biomass can negatively impact grain yield. The occurrence of TriMV and WSMV in the same wheat crop can exacerbate yield loss due to the synergistic interaction of the two viruses when they co-infect individual wheat plants $(32,33)$. Hence, there is a need to quantify the effect of co-infection of winter wheat with TriMV and WSMV on yield and yield determinants in susceptible and resistant cultivars. In this greenhouse study, we quantified the effects on yield determinants of single and double infections of a WSMV-susceptible cultivar and a WSMVresistant cultivar by TriMV and WSMV.

\section{Materials and Methods}

Virus inoculum source, maintenance, and preparation. WSMV Sidney 81 isolate was obtained from an infectious cDNA clone (33). A TriMV isolate was originally obtained from wheat plants collected from a field in Red Willow County, NE and purified by inoculating crude sap at high dilutions $(1: 6,600)$ to singleleaf-stage seedlings of 'Tomahawk' wheat for three successive passages (34). Both viruses were maintained on winter wheat 'Millennium' (PI 613099) in a greenhouse room that was kept free of WCM to avoid possible contamination with WMoV. The absence of $\mathrm{WMoV}$, which is not mechanically transmitted, was confirmed by the absence of virus symptoms on noninoculated control plants. TriMV and WSMV inocula were prepared from the top fully developed leaves of Millennium that exhibited severe symptoms of TriMV or WSMV in the greenhouse. The harvested leaves were ground in a general extraction buffer (1:10, wt/vol) using a mortar and pestle. The extraction buffer consisted of sodium sulfite $(6 \%)$, polyvinylpyrrolidone (molecular weight 24,000 to 40,$000 ; 85 \%$ ), and powdered chicken egg albumin (9\%) dissolved in phosphatebuffered saline Tween-20. TriMV+WSMV inoculum was prepared by mixing equal volumes of TriMV and WSMV inocula. TriMV or WSMV inoculum was further diluted 1:1 with extraction buffer to a final dilution of 1:20. The inoculum was placed on ice and immediately transported to the greenhouse for inoculation, which lasted approximately $30 \mathrm{~min}$.

Treatments and experimental design. Two winter wheat cultivars, Millennium (WSMV susceptible) and 'Mace' (PI 651043, WSMV resistant), were used in this study. Millennium is a popular winter wheat cultivar (36) released for its superior and broad adaptation to rainfed wheat production systems in Nebraska and adjacent states (2). Mace was recently released primarily for its resistance to WSMV and adaptation to rainfed and irrigated wheat production systems in Nebraska and adjacent states (8). Two replicate experiments were conducted. Seed of the two cultivars was planted in 38-cm-diameter pots on 5 November 2010 (experiment 1) and 4 January 2011 (experiment 2). The potting mix consisted of $33 \%$ clay loam soil, $33 \%$ peat soil, $16.5 \%$ sand, and $16.5 \%$ vermiculite. Plants were maintained on a greenhouse bench. Temperature in the greenhouse ranged between $21^{\circ} \mathrm{C}$ minimum (nighttime) and $27^{\circ} \mathrm{C}$ maximum (daytime). The lighting regime was $14 \mathrm{~h}$ of light and $10 \mathrm{~h}$ of darkness. Plants were watered twice daily in the morning and in the evening and were fertilized with a water-soluble 20-10-20, N-P-K fertilizer (Peter's Professional Peat-Lite special; Everris, Marysville, $\mathrm{OH}$ ) at $250 \mathrm{ppm} 5$ days a week. To obtain sufficient samples for measurement of dependent variables, an experimental unit consisted of four pots (rather than one pot) and each pot was thinned to 12 plants.

At the two-leaf growth stage, both cultivars were mechanically inoculated with either TriMV, WSMV, or TriMV+WSMV in the greenhouse by gently rubbing Carborundum-dusted leaves with a pestle dipped in the respective virus inoculum. A fourth treatment (control) consisted of rubbing Carborundum-dusted leaves with a pestle dipped in sterile water. Previous experiments showed no difference in infectivity between sap prepared with sterile water and sap prepared with $20 \mathrm{mM}$ phosphate buffer at pH 7.0 (S. Tatineni, unpublished). At the termination of each replicate experiment at $28 \mathrm{DAI}$, presence of TriMV or WSMV in plants from each virusinoculated treatment was confirmed with enzyme-linked immunosorbent assay. The experimental design for each of the two experiments was a split plot in randomized complete blocks with four replicates. Main plots were the cultivars and subplots were the inoculation treatments.

Yield determinants. Relative chlorophyll content was assessed nondestructively (25) every 4 days beginning 4 DAI using a chlorophyll meter (soil plant analysis development [SPAD], model 502 Plus; Konica Minolta Sensing, Inc., Osaka, Japan; 9). In each treatment, 10 SPAD readings were taken and averaged. Higher SPAD

Table 1. $P$ values from analysis of variance of data from a study conducted to determine the effect of single and double infections of two winter wheat cultivars by Triticum mosaic virus and Wheat streak mosaic virus on yield determinants ${ }^{\mathrm{Z}}$

\begin{tabular}{|c|c|c|c|c|c|c|c|c|c|c|}
\hline $\begin{array}{l}\text { Source of } \\
\text { variation }\end{array}$ & df & $\begin{array}{c}\text { Final SPAD } \\
\text { reading }\end{array}$ & AUSPC & TPP & SFW & SDW & RFW & RDW & $\begin{array}{c}\text { Total } \\
\text { nitrogen }\end{array}$ & $\begin{array}{c}\text { Total } \\
\text { carbon }\end{array}$ \\
\hline Experiment (E) & 1 & 0.0016 & 0.0549 & 0.0007 & 0.0003 & 0.0001 & 0.0127 & 0.8933 & 0.0003 & 0.0401 \\
\hline Replication (R) & 6 & $\ldots$ & $\ldots$ & $\ldots$ & $\ldots$ & $\ldots$ & $\ldots$ & $\ldots$ & $\ldots$ & $\ldots$ \\
\hline Cultivar (C) & 1 & $<0.0001$ & 0.5203 & 0.3827 & 0.0010 & 0.0165 & 0.0030 & 0.0148 & $<0.0001$ & 0.5369 \\
\hline $\mathrm{E} \times \mathrm{C}$ & 1 & 0.2790 & 0.1783 & 0.6271 & 0.0977 & 0.7174 & 0.2550 & 0.8961 & 0.0022 & 0.0362 \\
\hline Error (a) & 6 & $\ldots$ & $\ldots$ & $\ldots$ & $\ldots$ & $\ldots$ & $\ldots$ & $\ldots$ & $\ldots$ & $\ldots$ \\
\hline Inoculation (I) & 3 & $<0.0001$ & 0.0035 & 0.1009 & $<0.0001$ & $<0.0001$ & $<0.0001$ & $<0.0001$ & $<0.0001$ & 0.3240 \\
\hline $\mathrm{E} \times \mathrm{I}$ & 3 & $<0.0001$ & 0.0522 & 0.0998 & 0.0179 & 0.0630 & 0.2276 & 0.0250 & 0.0443 & 0.0106 \\
\hline $\mathrm{C} \times \mathrm{I}$ & 3 & $<0.0001$ & 0.0088 & 0.0070 & $<0.0001$ & $<0.0001$ & $<0.0001$ & $<0.0001$ & 0.0001 & 0.0200 \\
\hline $\mathrm{E} \times \mathrm{C} \times \mathrm{I}$ & 3 & 0.3822 & 0.0442 & 0.6346 & 0.0026 & 0.021 & 0.1237 & 0.6102 & 0.6148 & 0.2145 \\
\hline Error (b) & 36 & $\ldots$ & $\ldots$ & $\ldots$ & $\ldots$ & $\ldots$ & $\ldots$ & $\ldots$ & $\ldots$ & $\ldots$ \\
\hline Total & 63 & $\ldots$ & $\ldots$ & $\ldots$ & $\ldots$ & $\ldots$ & $\ldots$ & $\ldots$ & $\ldots$ & $\ldots$ \\
\hline
\end{tabular}

\footnotetext{
${ }^{\mathrm{z}}$ Abbreviations: df, degrees of freedom; AUSPC, area under the soil plant analysis development (SPAD) progress curve; TPP, tillers per plant; SFW, shoot
} fresh weight; SDW, shoot dry weight; RFW, root fresh weight; and RDW, root dry weight. 
readings indicate higher intensity of greenness of leaf tissue (mild symptoms) and lower SPAD readings indicate lower chlorophyll levels and more severe symptoms $(8,9)$. The number of tillers per pot was determined at $28 \mathrm{DAI}$ and divided by the number of plants per pot to obtain the number of tillers per plant (TPP). Plants in each pot were cut at the soil surface at 28 DAI and shoot fresh weight (SFW) was determined. Roots were washed with pressurized water and dried with paper towels, and the root fresh weight
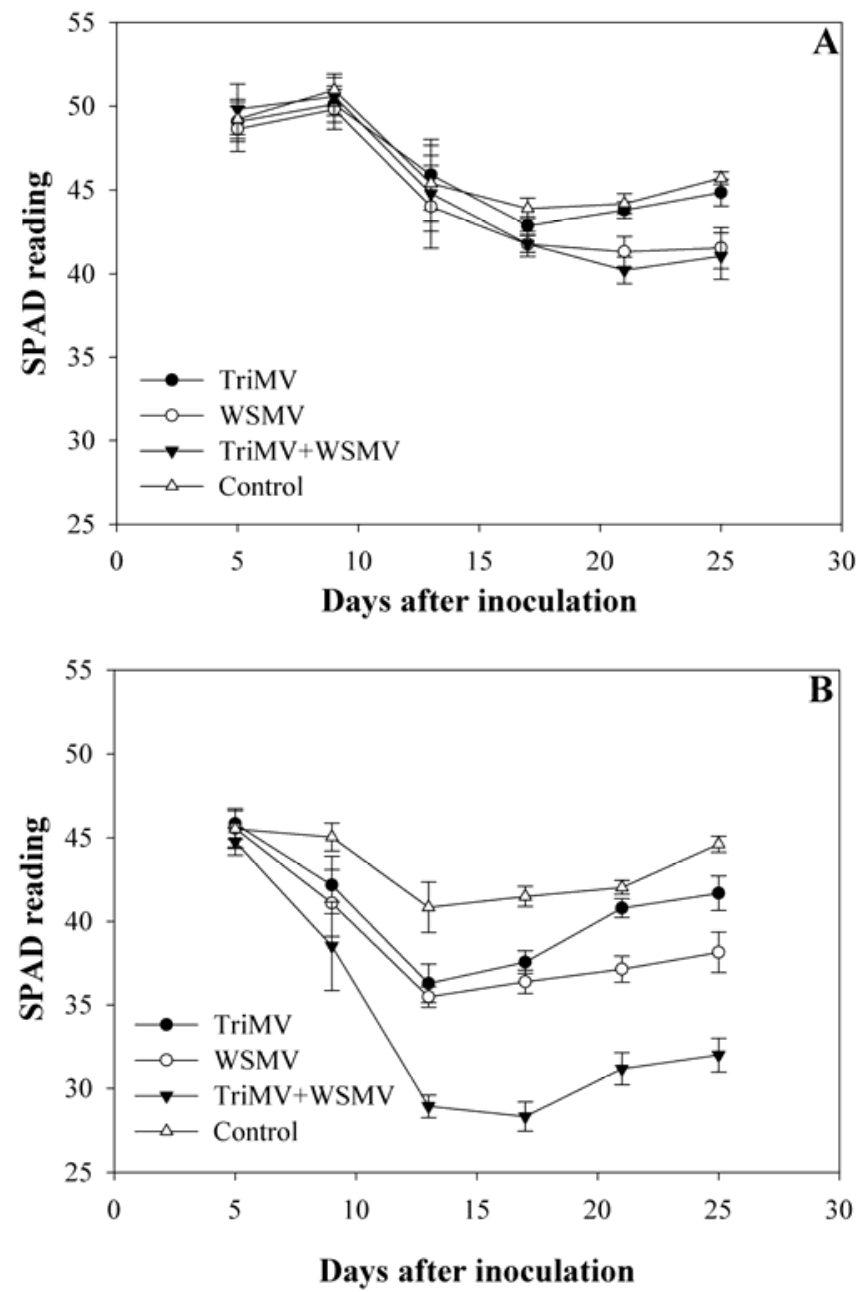

Fig. 1. Soil plant analysis development (SPAD) readings over time in winter wheat A, 'Mace' and B, 'Millennium' inoculated with Triticum mosaic virus (TriMV), Wheat streak mosaic virus (WSMV), TriMV+WSMV, or sterile water (control).
(RFW) was determined. The shoots and roots were then dried for $48 \mathrm{~h}$ at $60^{\circ} \mathrm{C}$ in a hot-air-blast oven and shoot dry weight (SDW) and root dry weight (RDW) were determined. Dry shoot samples were ground to powder and total nitrogen and total carbon for shoots (percent by weight) were determined using a combustion analysis method (1) in a Costech Analytical Elemental Combustion System 4010 (Costech Analytical Technologies, Inc., Valencia, CA).

Data analysis. SPAD readings were graphed against the observation date (DAI) to compare changes in chlorophyll content among different treatments over time. Trapezoidal integration was used to calculate area under the SPAD progress curve (AUSPC) as described by Madden et al. (21). The variables final SPAD reading, AUSPC, TPP, SFW, SDW, RFW, RDW, total nitrogen, and total carbon were subjected to analysis of variance using PROC GLM (SAS v.9.2; SAS Institute Inc., Cary, NC). Data from the two experiments were combined based on the $F$ ratio test for each variable (23). PROC GLIMMIX (SAS v.9.2) was used to separate cultivar-inoculation interaction least squares means at $P=0.05$. Fixed effects were experiment, cultivar, and inoculation. Replication and residual error were the random effects. To determine the relationship for each cultivar between relative chlorophyll content (SPAD readings) and shoot weight, the data (total of eight treatment means for each variable within a cultivar from the two experiments) were subjected to linear regression analysis using PROC REG (SAS v.9.2; SAS Institute Inc.). The relationship for each cultivar between shoot weight and total nitrogen was similarly modeled using PROC REG.

\section{Results}

Yield determinants. Chlorophyll content over time as measured by the chlorophyll meter (SPAD readings) differed among inoculation treatments in the two cultivars (Table 1; Fig. 1). There was a significant inoculation-cultivar interaction for final SPAD reading $(P<0.0001)$ and AUSPC $(P=0.0088)$ (Table 1$)$. Overall, in virus inoculation treatments, final SPAD and AUSPC values in Mace were higher than those in Millennium. In the control treatment, AUSPC was higher in Mace than in Millennium; however, the two cultivars did not significantly differ in final SPAD values (Fig. 1; Table 2).

In Mace, SPAD values over time for the TriMV treatment were similar to those in the control treatment and were consistently higher than those in the TriMV+WSMV and WSMV treatments throughout the sampling period (Fig. 1A). Similarly, final SPAD and AUSPC values in the TriMV treatment did not differ from those in the control treatment but were significantly higher than those in the WSMV and TriMV+WSMV treatments (Table 2). In Millennium, SPAD values throughout the sampling period were highest in the control treatment, intermediate in the TriMV or WSMV treatment, and lowest in the TriMV+WSMV treatment

Table 2. Treatment means from a study conducted to determine the effect of single and double infections of two winter wheat cultivars by Triticum mosaic virus (TriMV) and Wheat streak mosaic virus (WSMV) on yield determinants ${ }^{\mathrm{z}}$

\begin{tabular}{|c|c|c|c|c|c|c|c|c|c|}
\hline $\begin{array}{l}\text { Cultivar, } \\
\text { treatment }\end{array}$ & $\begin{array}{c}\text { Final SPAD } \\
\text { reading }\end{array}$ & AUSPC & TPP & SFW (g) & SDW (g) & RFW (g) & RDW (g) & $\begin{array}{c}\text { Total } \\
\text { nitrogen (\% } \\
\text { by weight) }\end{array}$ & $\begin{array}{c}\text { Total } \\
\text { carbon (\% } \\
\text { by weight) }\end{array}$ \\
\hline \multicolumn{10}{|l|}{ Mace } \\
\hline TriMV & $44.8 \mathrm{a}$ & $45.9 \mathrm{a}$ & $5.9 \mathrm{bc}$ & $50.6 \mathrm{bc}$ & $7.5 \mathrm{c}$ & $21.9 \mathrm{a}$ & $2.6 \mathrm{ab}$ & $5.1 \mathrm{~b}$ & $40.0 \mathrm{ab}$ \\
\hline WSMV & $41.5 \mathrm{~b}$ & $44.4 \mathrm{~b}$ & $5.9 \mathrm{bc}$ & $55.7 \mathrm{ab}$ & $8.0 \mathrm{ab}$ & $20.5 \mathrm{ab}$ & $2.7 \mathrm{a}$ & $5.1 \mathrm{~b}$ & $39.7 \mathrm{bc}$ \\
\hline TriMV+WSMV & $41.1 \mathrm{~b}$ & $44.6 \mathrm{~b}$ & $6.1 \mathrm{abc}$ & $53.4 \mathrm{~b}$ & $7.9 \mathrm{bc}$ & $19.1 \mathrm{bc}$ & $2.3 \mathrm{bc}$ & $4.8 \mathrm{c}$ & $40.0 \mathrm{ab}$ \\
\hline Control & $45.7 \mathrm{a}$ & $46.4 \mathrm{a}$ & $5.9 \mathrm{bc}$ & $54.3 \mathrm{~b}$ & $7.8 \mathrm{bc}$ & $21.7 \mathrm{ab}$ & $2.8 \mathrm{a}$ & $5.4 \mathrm{a}$ & $39.8 \mathrm{abc}$ \\
\hline \multicolumn{10}{|l|}{ Millennium } \\
\hline TriMV & $41.7 \mathrm{~b}$ & $40.1 \mathrm{~d}$ & $6.2 \mathrm{ab}$ & $47.0 \mathrm{c}$ & $7.3 \mathrm{c}$ & $16.9 \mathrm{~cd}$ & $2.2 \mathrm{bc}$ & $4.7 \mathrm{c}$ & 39.6 bc \\
\hline WSMV & $38.2 \mathrm{c}$ & $38.4 \mathrm{e}$ & $6.8 \mathrm{a}$ & $49.8 \mathrm{bc}$ & $7.5 \mathrm{c}$ & $15.5 \mathrm{~d}$ & $2.0 \mathrm{c}$ & $4.7 \mathrm{c}$ & $40.1 \mathrm{ab}$ \\
\hline TriMV+WSMV & $32.0 \mathrm{~d}$ & $33.1 \mathrm{f}$ & $5.5 \mathrm{c}$ & $25.2 \mathrm{~d}$ & $4.7 \mathrm{~d}$ & $6.2 \mathrm{e}$ & $0.8 \mathrm{~d}$ & $3.8 \mathrm{~d}$ & $39.2 \mathrm{c}$ \\
\hline Control & $44.6 \mathrm{a}$ & $42.9 \mathrm{c}$ & $6.4 \mathrm{ab}$ & $61.2 \mathrm{a}$ & $8.6 \mathrm{a}$ & $21.1 \mathrm{ab}$ & $3.0 \mathrm{a}$ & $5.1 \mathrm{~b}$ & $40.3 \mathrm{a}$ \\
\hline
\end{tabular}

${ }^{\text {z }}$ Abbreviations: SPAD, soil plant analysis development; AUSPC, area under the SPAD progress curve; TPP, tillers per plant; SFW, shoot fresh weight; SDW, shoot dry weight; RFW, root fresh weight; and RDW, root dry weight. Means followed by the same letter within a column are not significantly different according to the least significant difference test at $P=0.05$. 
(Fig. 1B). Final SPAD and AUSPC values differed among all treatments, with the highest values in the control treatment and the lowest values in the TriMV+WSMV treatment. Final SPAD and AUSPC values were significantly higher in the TriMV than in the WSMV treatment (Table 2).

The $F$ values for cultivar and inoculation were not significant for number of TPP (Table 1). However, cultivar-inoculation interaction was significant $(P=0.007)$. Only the TriMV+WSMV treatment in Millennium significantly reduced TPP (Table 2). In the control treatment, the two cultivars did not significantly differ in TPP.

Effects of cultivar, inoculation, and inoculation-cultivar interaction were highly significant $(P \leq 0.017)$ for both SFW and SDW (Table 1). Overall, in the virus inoculation treatments, SFW and SDW were higher in Mace than in Millennium. In the control treatment, SFW and SDW were significantly higher in Millennium than in Mace (Table 2). In Mace, SFW and SDW did not differ between the control treatment and the virus inoculation treatments (Table 2). In Millennium, however, SFW and SDW varied among virus inoculation treatments. The TriMV+WSMV treatment had the lowest SFW (59\% reduction) and SDW (45\% reduction). The TriMV and WSMV treatments did not significantly differ in SFW and SDW (Table 2).

RFW and RDW were significantly impacted by both cultivar ( $P$ $\leq 0.015)$ and virus inoculation $(P<0.0001)$ (Table 1$)$. The $F$ value for cultivar-inoculation interaction was also highly significant $(P<$
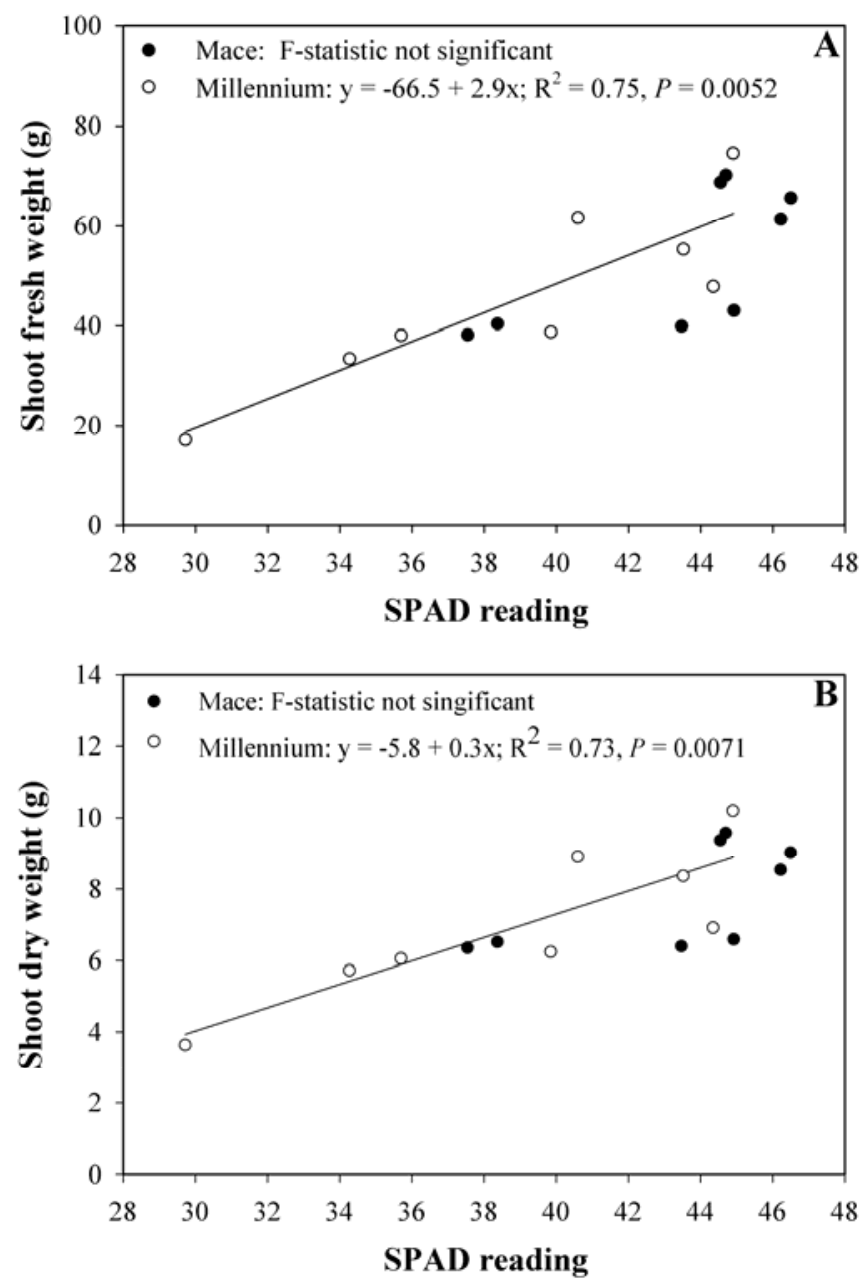

Fig. 2. A, Relationship between shoot fresh weight and soil plant analysis development (SPAD) readings in winter wheat 'Mace' and 'Millennium' and B, relationship between shoot dry weight and SPAD readings in winter wheat Mace and Millennium. Each cultivar was inoculated with Triticum mosaic virus (TriMV), Wheat streak mosaic virus (WSMV), TriMV+WSMV, or sterile water. Data points represent treatment means from two replicate experiments (four treatments by two experiments).
0.0001) for both RFW and RDW. Overall, in the virus inoculation treatments, RFW and RDW were higher in Mace than in Millennium. In the control treatment, the two cultivars did not significantly differ in RFW and RDW (Table 2). In Mace, only the TriMV+WSMV RDW was significantly lower than the noninoculated control RDW. In Millennium, however, RFW and RDW in all virus inoculation treatments were significantly lower than in the control treatment. RFW and RDW did not differ between the TriMV and WSMV treatments but were significantly higher than in the TriMV+WSMV treatment. Therefore, the TriMV+WSMV treatment in Millennium had the lowest RFW (71\% reduction) and RDW (73\% reduction).

The effects of cultivar and virus inoculation on total nitrogen were highly significant $(P<0.0001)$. Cultivar-inoculation interaction was also highly significant $(P=0.0001$; Table 1$)$. Total nitrogen in all treatments was higher in Mace than in Millennium. In both cultivars, total nitrogen in all virus inoculation treatments was significantly lower than in the control treatment. In Mace, total nitrogen was lowest in the TriMV+WSMV treatment $(11 \%$ reduction) followed by the WSMV and TriMV treatments (6\% reduction). In Millennium, the greatest reduction in total nitrogen occurred in the TriMV+WSMV treatment (25\% reduction) and the least reduction occurred in the TriMV and WSMV treatments $(8 \%$ reduction). In contrast to total nitrogen, the $F$ values for cultivar and inoculation effects were not significant for total carbon. Total carbon in virus inoculation treatments did not differ from total carbon in the control treatment in Mace, and only the TriMV and TriMV+WSMV treatments had significantly lower total carbon than the control treatment in Millennium. Reduction in total carbon was less than $1 \%$ in the TriMV and TriMV+WSMV treatments in Millennium (Table 2). In the control treatment, the two cultivars did not significantly differ in total carbon.

Relationship between shoot weight and SPAD readings. SPAD readings and SFW had a significant positive linear relationship in Millennium $(P=0.0052)$ but not in Mace $(P=0.0561)$ (Fig. 2A). In Millennium, SPAD readings explained $75 \%$ of the variation in SFW. SDW also had a significant positive linear relationship with SPAD readings in Millennium $(P=0.0071)$ but not in Mace $(P=0.0771)$, with SPAD readings explaining $73 \%$ of the variation in SDW in Millennium (Fig. 2B).

Relationship between shoot weight and total nitrogen. There was a significant, positive linear relationship between SFW and total nitrogen in both Millennium $(P=0.0002)$ and Mace $(P=$ 0.0024 ) (Fig. 3A). Total nitrogen explained $91 \%$ of the variation in SFW in Millennium and $81 \%$ of the variation in SFW in Mace. Similarly, there was a significant, positive linear relationship between SDW and total nitrogen in both Millennium $(P=0.0002)$ and Mace $(P=0.0041)$, with total nitrogen explaining $77 \%$ of the variation in SDW in Mace and $91 \%$ of the variation in SDW in Millennium (Fig. 3B).

\section{Discussion}

This study demonstrated, under greenhouse conditions, a synergistic, negative effect on yield determinants when a WSMV-resistant cultivar (Mace) and a WSMV-susceptible cultivar (Millennium) were co-infected with TriMV and WSMV. These effects were more pronounced in the susceptible cultivar compared with the resistant cultivar and were correlated with symptom severity, which was quantified as SPAD readings (decreasing SPAD readings indicate increasing severity of disease symptoms on virusinfected plants). SPAD readings in Mace in all virus inoculation treatments, as indicated by final SPAD values and AUSPC, were significantly higher than in Millennium. Even the TriMV+WSMV treatment, which caused severe symptoms in Millennium, elicited only mild symptoms in Mace, indicating that, under greenhouse conditions, Mace was resistant to both WSMV and TriMV, and that this resistance is not diminished by co-infection with the two viruses. Resistance to WSMV in Mace is conditioned by the Wsm-1 gene (8). It is likely that this same gene conditions resistance to TriMV in Mace. 
It is notable that, in both Mace and Millennium, TriMV caused milder symptoms (higher SPAD readings) than WSMV (Table 2). However, single infections by these viruses caused more severe symptoms in Millennium than in Mace. When both cultivars were co-infected with TriMV and WSMV, synergism in symptom expression was more pronounced in the WSMV-susceptible Millennium. These results are consistent with the results of Tatineni et al. (33), who demonstrated that, at 20 to $26^{\circ} \mathrm{C}$ (conditions similar to those in the current study), co-infection of the WSMV-susceptible winter wheat 'Arapahoe' and Tomahawk with TriMV and WSMV caused severe symptoms (chlorosis, chlorotic stripes, leaf deformation, and bleaching) whereas the same treatment caused only mild to moderate symptoms in Mace.

Tillering in wheat is one of the factors that contributes most to production of high spike numbers and grain yield (4). Infection of winter wheat by WSMV has been shown to significantly reduce tillering (14) and plant height (15). In this study, none of the virus inoculation treatments had an effect on TPP in Mace. However, in Millennium, the TriMV+WSMV treatment, and not the single virus treatments, significantly reduced TPP, indicating the potential for greater yield reduction when the WSMV-susceptible cultivar is coinfected by both viruses. Under field conditions, Hunger et al. (14) similarly showed that, when winter wheat cultivars were inoculated with WSMV in the fall, reduction in tiller number was greater in susceptible cultivars than in a moderately resistant cultivar. In the current study, seed of Millennium and Mace was not vernalized. It is possible that the effect of virus infection on TPP would have differed from the current results if seed of both cultivars was vernalized. Vernalization has been shown to increase tillering in the early stages of growth in winter wheat, and the extent of the increased tillering varies among cultivars (3).

In this study, SFW and SDW were not affected by all virus inoculation treatments in Mace. However, in Millennium, both SFW and SDW were significantly reduced by all virus inoculation treatments, with the greatest reductions occurring in the TriMV+WSMV treatment. Similar results were observed for RFW and RDW, except that the TriMV+WSMV treatment also significantly reduced RDW in Mace. Previous studies have similarly demonstrated a significant, negative effect on biomass when winter wheat cultivars were infected with WSMV. Price et al. (24) showed that, under greenhouse conditions, when two winter wheat cultivars were inoculated with WSMV, reduction in root biomass was greater in the susceptible compared with the resistant cultivar. Larsen et al. (17) demonstrated under laboratory conditions that two susceptible winter wheat cultivars had similar reductions in their shoot or root growth when inoculated with WSMV. They further observed that shoot growth was less affected by WSMV infection than root growth. This latter observation is in agreement with the finding in the current study, in which the WSMV treatment in Millennium resulted in a greater reduction in root biomass $(27 \%$ reduction in RFW and 33\% reduction in RDW) than in shoot biomass (19\% reduction SFW and $13 \%$ reduction in SDW). It is notable that, in the control treatment, SFW and SDW were significantly higher in Millennium than in Mace, indicating a higher yield potential in Millennium compared with Mace in the absence of virus infection. In rainfed state trials, the 5-year yield average for 2007 to 2011 was $4,371 \mathrm{~kg} / \mathrm{ha}$ for Millennium compared with $3,901 \mathrm{~kg} / \mathrm{ha}$ for Mace in west-central Nebraska and 3,632 kg/ha for Millennium compared with 3,160 kg/ha for Mace in western Nebraska (7).

All virus inoculation treatments significantly reduced total nitrogen in both Mace and Millennium. However, the reduction was greater in Millennium than in Mace and greatest in the TriMV+WSMV treatment in both cultivars. A common effect of viruses that cause mosaic and yellowing diseases is a reduction in the amount of the most abundant host protein, ribulose biphospate carboxylase-oxygenase (rubisco) (13). White and Brakke (38) found that, when wheat was infected with WSMV and barley was infected with Barley stripe mosaic virus (Hordeivirus, Virgaviridae), the proteins that decreased in amount were similar in both hosts, and one of these proteins was rubisco. Many of the proteins were identified as chloroplast proteins. The authors (38) suggested that virus infection reduces chloroplast ribosomal proteins. Guo et al. (10) found that chlorophyll content in leaves of stem mustard (Brassica juncea var. tsatsai) was significantly reduced 2 weeks after infection by Turnip mosaic virus (Potyvirus, Potyviridae). In this study, the expression of more severe symptoms (as indicated by SPAD readings) in Millennium than in Mace when both cultivars were infected with TriMV, WSMV, or TriMV+WSMV is consistent with the greater reduction in total nitrogen in Millennium than in Mace, because nitrogen is essential for protein synthesis (18). Kandhasamy et al. (16) similarly observed a significant reduction in nitrogen when finger millet plants were infected with Mottle streak virus (Rhabdovirus, Rhabdoviridae).

In contrast to the significant reduction in total nitrogen by virus inoculation treatments in both Mace and Millennium, total carbon was largely unaffected by virus infection in both cultivars. Only the TriMV+WSMV treatment in Millennium significantly reduced total carbon, and this reduction was very small. The effect of viruses on carbohydrates in leaves is variable, with some viruses having little effect and others altering the rate of carbohydrate synthesis and translocation (13). In this study, the TriMV+WSMV treatment significantly reduced total carbon in the WSMVsusceptible Millennium. Reduction in total carbon may be due to effects of virus infection on respiration or alterations in carbohydrate metabolism. Tecsi et al. (35) demonstrated that, when cotyle-
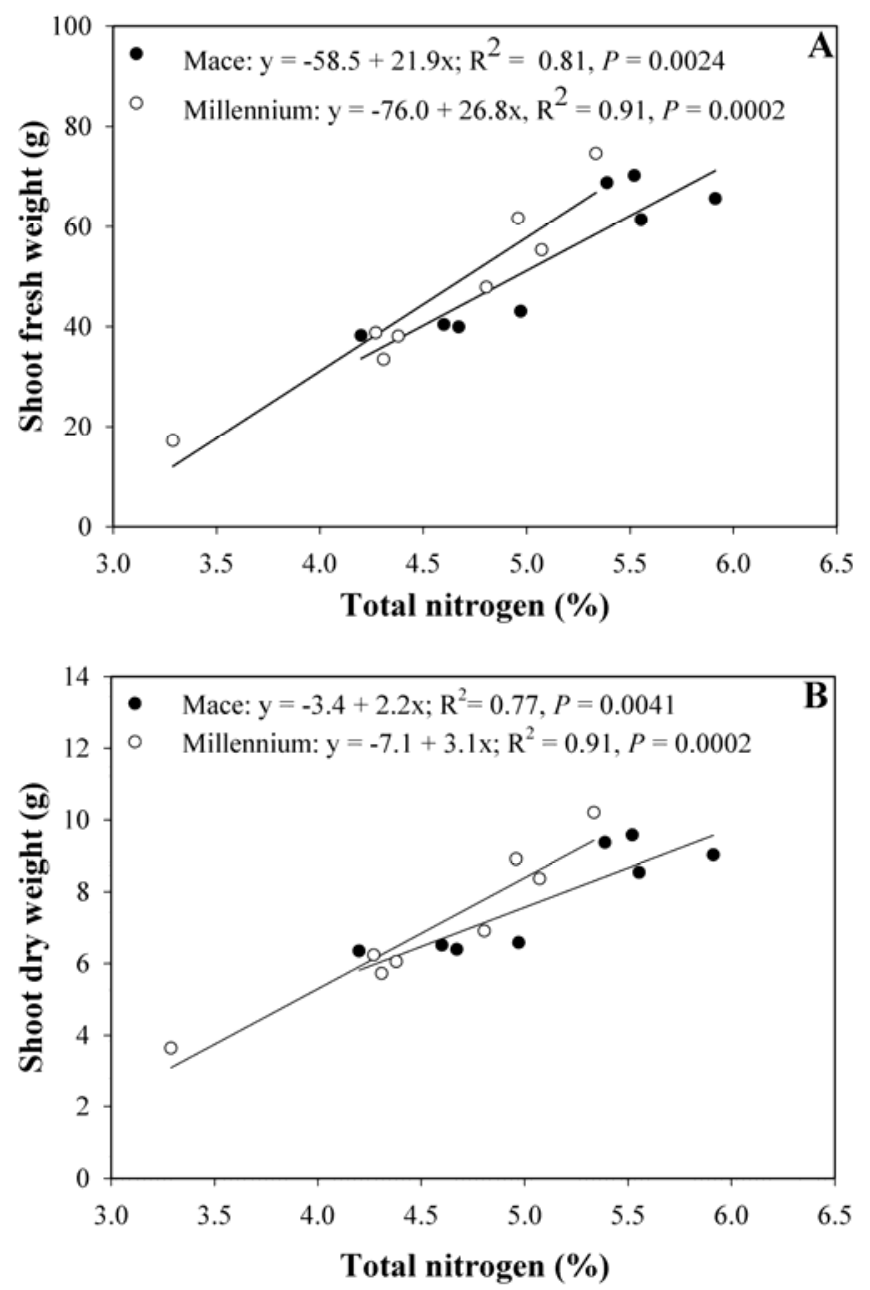

Fig. 3. A, Relationship between shoot fresh weight and total nitrogen (\%) in winter wheat 'Mace' and 'Millennium' and B, relationship between shoot dry weight and nitrogen in winter wheat Mace and Millennium B. Each cultivar was inoculated with Triticum mosaic virus (TriMV), Wheat streak mosaic virus (WSMV), TriMV+WSMV, or sterile water. Data points represent treatment means from two replicate experiments (four treatments by two experiments). 
dons of marrow (Cucurbita pepo) were infected with Cucumber mosaic virus (Cucumovirus, Bromoviridae), respiration increased dramatically and starch declined in the later stages of infection, and the decline in starch was correlated with a reduced capacity for starch synthesis and a rise in the capacity for starch degradation. Reduction in total carbon may also be due to reduced photosynthesis caused by chlorophyll depletion.

The relationship between SPAD readings and shoot weight was linear, positive, and significant in Millennium but not in Mace. This was expected because, in Millennium, the effect of virus infection on biomass and symptom severity was greater, resulting in a wider range of SPAD readings and corresponding shoot weights. In contrast, the relationship between total nitrogen and shoot weight was linear, positive, and significant in both Mace and Millennium. This was because the effect of virus infection on total nitrogen was significant and similar in both cultivars, although it was more pronounced in Millennium than in Mace.

This study demonstrated that both single and double infections of winter wheat by TriMV and WSMV have a negative effect on yield determinants (biomass, tillers, total nitrogen, and total carbon). This effect was more pronounced in a WSMV-susceptible cultivar (Millennium) than in a WSMV-resistant cultivar (Mace), and most pronounced in a double infection of the susceptible cultivar. The results indicate that Mace is also resistant to TriMV and that double infection of a susceptible winter wheat cultivar by both viruses exacerbates symptom expression and loss of biomass.

\section{Acknowledgments}

Funding for this work was provided by the Agriculture and Food Research Initiative Competitive Grants Program Grant Number 2010-85605-20546 from the National Institute of Food and Agriculture.

\section{Literature Cited}

1. AOAC. 2005. Official Methods of Analysis of AOAC International, 18th ed. Assoc. Office Anal. Chem., Arlington, VA.

2. Baenziger, P. S., Moreno-Sevilla, B., Peterson, C. J., Shelton, D. R., Elmore, R. W., Nordquiest, P. T, Klein, R. N., Baltensperger, D. D., Nelson, L. A., McVey, D. V., Watkins, J. E., Hein, G., and Hatchett, H. J. 2001. Registration of 'Millennium' wheat. Crop Sci. 41:1367-1369.

3. Bell, G. D. H. 1936. Experiments on vernalisation. J. Agric. Sci. 26:155171.

4. Bulman, P., and Hunt, L.A. 1988. Relationships among tillering, spike number and grain yield in winter wheat (Triticum aestivum L.) in Ontario. Can. J. Plant Sci. 68:583-596.

5. Burrows, M., Franc, G., Rush, C., Blunt, T., Ito, D., Kinzer, K., Olson, J., O'Mara, J., Price, J., and Tande, C. 2009. Occurrence of viruses in wheat in the Great Plains region, 2008. Plant Health Progress. Online publication. doi:10.1094/PHP-2009-0706-01-RS.

6. Edwards, M. C., and McMullen, M. P. 1988. Variation in tolerance to wheat streak mosaic virus among cultivars of hard red spring wheat. Plant Dis. 72:705-707.

7. Fall Seed Guide 2011. University of Nebraska-Lincoln Extension. Online publication. http://www.ianrpubs.unl.edu/epublic/live/ec103/build/ec103. pdf.

8. Graybosch, R., Peterson, C., Baenziger, P., Baltensperger, D., Nelson, L., Jin, Y., Kolmer, J., Seabourn, B., French, R., and Hein, G. 2009. Registration of 'Mace' hard red winter wheat. J. Plant Reg. 3:51-56.

9. Guinta F., Motzo R., and Deidda, M. 2002. SPAD readings and associated leaf traits in durum wheat, barley and triticale cultivars. Euphytica 125:197-205.

10. Guo, D. P., Guo, Y. P., Zhao, J. P., Liu, H., Peng, Y., Wang, Q. M., Chen, J. S., and Rao, G. Z. 2005. Photosynthetic rate and chlorophyll fluorescence in leaves of stem mustard (Brassica juncea var. tsatsai) after turnip mosaic virus infection. Plant Sci. 168:57-63.

11. Haley, S. D., Johnson, J. J., Peairs, F. B., Stromberger, J. A., Heaton, E. E., Seifert, S. A., Kottke, R. A., Rudolf, J. B., Martin, T. J., Bai, G., Chen, X., Bowden, R. L., Jin, Y., Kolmer, J. A., Seifers, D. L., Chen, M-S., and Seabourn, B. W. 2011. Registration of 'Snowmass' wheat. J. Plant Reg. 5:87-90

12. Howell, A. T. 1990. Grain, dry matter yield relationship for winter wheat and grain sorghum - southern high plains. Agron. J. 82:914-918.

13. Hull R. 2002. Matthews' Plant Virology. Elsevier Academic Press, San Diego, CA.

14. Hunger, R. M., Sherwood, J. L., Evans, C. K., and Montana, J. R. 1992.
Effects of planting date and inoculation date on severity of wheat streak mosaic in hard red winter wheat cultivars. Plant Dis. 76:1056-1060.

15. Jimenez-Martinez, S. E., and Bosques-Perez, N. A. 2009. Life history of the bird cherry-oat aphid, Rhopalosiphum padi, on transgenic and non-transformed wheat challenged with Wheat streak mosaic virus. Entomol. Exp. Appl. 133:19-26.

16. Kandhasamy, S., Ambalavanan, S., and Palanisamy, M. 2010. Changes in physiology and biochemistry of mottle streak virus infected finger millet plants. Arch. Phytopathol. Plant Prot. 43:1273-1285.

17. Larsen, J.H., Brakke, M. K., and Langernberg, W. G. 1985. Relationship between wheat streak mosaic virus and soilborne wheat virus infection, disease resistance, and early growth of winter wheat. Plant Dis. 69:857-862.

18. Lawlor, W. D. 2002. Carbon and nitrogen assimilation in relation to yield: Mechanisms are the key to understanding production systems. J. Exp. Biol. 773-787.

19. Lommel, S. A., Willis, W. G., and Kendall, T. L. 1986. Identification of wheat spindle streak mosaic virus and its role in a new disease of winter wheat in Kansas. Plant Dis. 70:964-968.

20. Lu, H., Price, J., Devkota, R., Rush C., and Rudd, J. 2011. A dominant gene for resistance to Wheat streak mosaic virus in winter wheat line CO9602932. Crop Sci. 51:5-12.

21. Madden, L., Hughes, G., and van den Bosch, F. 2007. The Study of Plant Disease Epidemics. American Phytopathological Society, St. Paul, MN.

22. Martin, T. J., Fritz, A. K., Seifers, D., and Shroyer, J. P. 2007. RonL hard white wheat. L-926, Kansas State University Agricultural Experiment Station and Cooperative Extension Service. Online publication. http://www. ksre.ksu.edu/library/crpsl2/1926.pdf

23. Miller, J. R., Jr. 1986. Beyond Anova, Basics of Applied Statistics. Wiley \& Sons, New York.

24. Price, J., Workneh, F., Evett, S., Jones, D., Arthur, J., and Rush, C. 2010. Effects of Wheat streak mosaic virus on root development and water-use efficiency of hard red winter wheat. Plant Dis. 94 :766-770.

25. Richardson, A. D., Duigan, S. P., and Berlyn, G. P. 2002. An evaluation of noninvasive methods to estimate foliar chlorophyll content. New Phytol 153:185-194.

26. Seifers, D. L., Martin, T., and Fellers, J. 2010. An experimental host range for Triticum mosaic virus. Plant Dis. 94:1125-1131.

27. Seifers, D. L., Martin, T., and Fellers, J. P. 2011. Occurrence and yield effects of wheat infected with Triticum mosaic virus in Kansas. Plant Dis. 95:183-188.

28. Seifers, D. L., Martin, T., Harvey, T. L., Fellers, J. P., and Michaud, J. 2009 Identification of the wheat curl mite as the vector of Triticum mosaic virus. Plant Dis. 93:25-29.

29. Seifers, D. L., Martin, T., Harvey, T. L., Fellers, J. P., Stack, J. P., RybaWhite, M., Haber, S., Krokhin, O., Spicer, V., and Lovat, N. 2008. Triticum mosaic virus: A new virus isolated from wheat in Kansas. Plant Dis. 92:808-817.

30. Seifers, D. L., Martin, T. J., Harvey, T. L., and Haber, S. 2007. Temperature sensitive Wheat streak mosaic virus resistance identified in KS03HW12 wheat. Plant Dis. 91:1029-1033.

31. Shahwan, I. M., and Hill, J. P. 1984. Identification and occurrence of Wheat streak mosaic virus in winter wheat in Colorado and its effects on several wheat cultivars. Plant Dis. 68:579-581.

32. Stenger, D. C., Young, B. A., Qu, F., Morris, T. J., and French, R. 2007. Wheat streak mosaic virus lacking helper component-proteinase is competent to produce disease synergism in double infections with Maize chlorotic mottle virus. Phytopathology 97:1213-221.

33. Tatineni, S., Graybosch, R. A., Hein, G. L., Wegulo, S. N., and French, R. 2010. Wheat cultivar-specific disease synergism and alteration of virus accumulation during co-infection with Wheat streak mosaic virus and Triticum mosaic virus. Phytopathology 100:230-238.

34. Tatineni, S., Ziems, A. D., Wegulo, S. N., and French, R. 2009. Triticum mosaic virus: A distinct member of the family Potyviridae with an unusually long leader sequence. Phytopathology 99:943-950.

35. Tecsi, L. I., Maule, A. J., Smith, A. M., and Leegood, R. C. 1994. Metabolic alterations in cotyledons of Cucurbita pepo infected by cucumber mosaic virus. J. Exp. Bot. 45:1541-1551.

36. United States Department of Agriculture. 2010. Nebraska Wheat Varieties. Online publication. http://www.nass.usda.gov/Statistics_by_State/Nebraska/ Publications/Crop_Variety_Reports/whet2010.pdf.

37. Velandia, M., Rejesus, R. M., Jones, D. C., Price, J. A., Workneh, F., and Rush, C. M. 2010. Economic impact of Wheat streak mosaic virus in the Texas High Plains. Crop Prot. 29:699-703.

38. White, J. L., and Brakke, M. K. 1983. Protein changes in wheat infected with wheat streak mosaic virus and in barley infected with barley stripe mosaic virus. Physiol. Plant Pathol. 22:87-100.

39. Workneh, F., Price, J., Jones, D., and Rush, C. 2010. Wheat streak mosaic: A classic case of plant disease impact on soil water content and crop wateruse efficiency. Plant Dis. 94:771. 